Bull. Chem. Soc. Ethiop. 2021, 35(2), 435-448.

(C) 2021 Chemical Society of Ethiopia and The Authors

ISSN 1011-3924

DOI: https://dx.doi.org/10.4314/bcse.v35i2.16

Printed in Ethiopia

Online ISSN 1726-801X

\title{
SCHIFF BASES DERIVED FROM 4-AMINO-N-SUBSTITUTED BENZENESULFON- AMIDE: SYNTHESIS, SPECTRAL CHARACTERISATION AND MIC EVALUATION
}

\author{
Govindaraj Valarmathy ${ }^{*}$, Ramanathan Subbalakshmi, Balachandran Sabarika ${ }^{*}$, Chinnadhurai \\ Nisha \\ PG and Research Department of Chemistry, Seethalakshmi Ramaswami College, Bharathidasan \\ University, Tiruchirappalli, Tiruchirappalli-620 002, Tamil Nadu, India
}

(Received September 10, 2019; Revised May 21, 2021; Accepted June 9, 2021)

\begin{abstract}
The present study is aimed to synthesise Schiff bases from sulfathiazole/ sulfamethoxazole/ sulfadimidine with 2-hydroxybenzaldehyde. The synthesized Schiff bases were characterized by analytical data, IR, ${ }^{1} \mathrm{H}-\mathrm{NMR},{ }^{13} \mathrm{C}-\mathrm{NMR}$, UV-Vis spectra, mass spectra and screened for antibacterial activity against gram positive bacteria Staphylococcus aureus and gram negative bacteria Salmonella typhiand antifungal activity against Candida albicans and Mucor by disc diffusion method. Zone of inhibition indicated that the Schiff base possessed highly potent antimicrobial activity when compared to sulpha drugs.
\end{abstract}

KEY WORDS: 4-Amino-N-(1,3-thiazol-2-yl)benzenesulfonamide, 4-amino-N-(5-methylisoxazol-3-yl)benzenesulfonamide,4-amino-N-(4,6-dimethylpyrimidin-2-yl)benzenesulfonamide, 2-hydroxybenzaldehyde, antimicrobial activity

\section{INTRODUCTION}

Schiff bases are condensation products of primary amine and carbonyl compounds and they were discovered by a German chemist, Noble prize wined Hugo Schiff in 1864 [1]. Schiff base ligands are essential in the field of coordination chemistry, especially in the development of complexes of Schiff bases because these compounds are potentially capable of stable complexes with metal ions [2].

A large number of Schiff base complexes are characterized by an excellent catalytic activity in a variety of reactions at high temperature $\left(>100{ }^{\circ} \mathrm{C}\right)$ and in the presence of moisture [3]. In recent years, there have been numerous reports of their use in homogeneous and heterogeneous catalysis [4]. They are increasingly being used as catalysts in various biological systems, polymers and dyes [5]. A large number of different Schiff bases ligands have been used as cation carriers in potentiometric sensors [6]. So much interest in imines can be explained by the fact that they are widely distributed in many biological systems and they are used in organic synthesis and chemical catalysis, medicine, pharmacy and chemical analysis, as well as new technologies [7].

Sulfonamides, also known as sulfa drugs were the first effective chemotherapeutics agents employed systematically for the prevention and cure of bacterial infections in humans. Many different families of organic and inorganic compounds are currently investigated today because of their applications. Sulfonamides and their N-derivatives are one of the outstanding groups. Sulfonamides represent are important compounds which are extensively used antibacterial agent. It interferes with $p$-aminobenzoic acid (PABA) in biosynthesis of tetrahydro folic acid which is a basic growth factor essential for the metabolic process of bacteria [8-10].

*Corresponding author. E-mail: valarchola@gmail.com, sabarikamsc17@gmail.com

This work is licensed under the Creative Commons Attribution 4.0 International License 


\section{EXPERIMENTAL}

All chemicals and reagents used were of AR grade except ethanol which was purified prior to use. Solvents were purified and dried according to the standard procedures. Elemental analysis of the ligand and complexes were obtained using ElementarVario EL CHN rapid analyzer. IR spectra of the complexes were recorded as KBr pellets on a SHIMADZU 8000 - FTIR spectrophotometer. The ${ }^{13} \mathrm{C}-\mathrm{NMR}$ and ${ }^{1} \mathrm{H}-\mathrm{NMR}$ spectra of the ligand was recorded with a Bruker Spectrospin Advance (DPX-400) using TMS as internal standard and DMSO- $\mathrm{d}^{6}$ as solvent. Melting points were determined by open capillary method (silicon bath electric melting point apparatus) and uncorrected.

\section{Synthesis of Schiff base ligand}

Synthesis of (E)-4-((2-hydroxybenzylidene)amine)-N-(thiazol-2-yl)benzene sulfonamide. To a hot stirred ethanolic solution of sulphathiazole $(0.001 \mathrm{~mol})$ an ethanolic solution of 2hydroxybenzaldehyde $(0.6 \mathrm{~mL})$ was added. The reaction mixture was refluxed for $5 \mathrm{~h}$. The yellow coloured solid mass formed during refluxing was cooled, filtered, washed thoroughly with ethanol and dried in a desiccator. The compound was purified by recrystallisation from ethanol (yield: $85 \%$, m.p. $220^{\circ} \mathrm{C}$ ).

Synthesis of 4-((2-hydroxy-benzylidine)-amine)- $N$-(methyl-1,2-oxazol-3-yl)-benzene sulphonamide. To a hot stirred ethanolic solution of 2-hydroxybenzaldehyde $(0.6 \mathrm{~mL})$ an ethanolic solution of sulphamethaoxazole $(0.001 \mathrm{~mol})$ was added. The reaction mixture was refluxed for 5 $\mathrm{h}$. The yellow coloured solid mass formed during refluxing was cooled, filtered, washed thoroughly with ethanol and dried in a desiccator. The compound was purified by recrystallisation from ethanol (yield: $85 \%$, m.p. $271^{\circ} \mathrm{C}$ ).

Synthesis of N-(4,6-dimethylpyrimidin-2-yl)-4-((2-hydroxybenzylidine) amino)benzene sulfonamide. To a hot stirred ethanolic solution of sulphadimidine $(0.001 \mathrm{~mol})$ anethanolic solution of 2-hydroxybenzaldehyde $(0.6 \mathrm{~mL})$ was added. The reaction mixture was refluxed for $5 \mathrm{~h}$. The yellow coloured solid mass formed during refluxing was cooled, filtered, washed thoroughly with ethanol and dried in a desiccator. The compound was purified by recrystallisation from ethanol (yield: $80 \%$, m.p. $264{ }^{\circ} \mathrm{C}$ ).

\section{RESULTS AND DISCUSSION}

In the present work, the Schiff bases 4-((2-hydroxybenzylidene)amino-N-(1,3-thiazol-2yl)benzenesulfonamide $) \quad\left(\mathrm{L}_{1}\right), \quad 4-((2$-hydroxy-benzylidine $)$-amino $)-\mathrm{N}-(5$-methyl-1,2-oxazol-3yl)benzenesulfonamide) $\left(\mathrm{L}_{2}\right)$, 4-((2-hydroxybenzylidene)amino)-N-(4,6-dimethylpyrimidin-2yl)-benzene sulfonamide $\left(\mathrm{L}_{3}\right)$ have been synthesized. The stoichiometry of the compounds has been determined by standard procedures.

Analytical data

The Schiff base ligand $\mathrm{L}_{1}$ was synthesized by condensing 2-hydroxy benzaldehyde and 4amino-N-(1,3-thiazol-2-yl)benzenesulfonamide. It is an orange colored solid with melting point $=270{ }^{\circ} \mathrm{C}$. The Schiff base ligand $\mathrm{L}_{2}$ was synthesized by condensing 2-hydroxy benzaldehyde and 4-amino-N-(5-methylisoxazol-3-yl)benzenesulfonamide. It is a yellow colored solid with melting point $=271{ }^{\circ} \mathrm{C}$. The Schiff base ligand $\mathrm{L}_{3}$ was synthesized by condensing 2-hydroxy benzaldehyde and 4-amino-N-(4,6-dimethylpyrimidin-2-yl)benzenesulfonamide. It is an orange colored solid with melting point $=264{ }^{\circ} \mathrm{C}$. The analytical data and physical characteristics of the Schiff base are (Table 1) indicates that the molecular formula as, $\mathrm{L}_{1}: \mathrm{C}_{16} \mathrm{H}_{13} \mathrm{~N}_{3} \mathrm{O}_{3} \mathrm{~S}_{2} ; \mathrm{L}_{2}$ : $\mathrm{C}_{17} \mathrm{H}_{15} \mathrm{~N}_{3} \mathrm{O}_{4} \mathrm{~S} ; \mathrm{L}_{3}: \mathrm{C}_{20} \mathrm{H}_{19} \mathrm{~N}_{3} \mathrm{O}_{3} \mathrm{~S}$. 
Table 1. Physical characteristics and analytical data of Schiff bases.

\begin{tabular}{|c|c|c|c|c|c|c|c|c|c|}
\hline \multirow[t]{2}{*}{$\begin{array}{l}\text { S. } \\
\text { No. }\end{array}$} & \multirow{2}{*}{$\begin{array}{c}\text { Schiff } \\
\text { base }\end{array}$} & \multirow{2}{*}{$\begin{array}{l}\text { Molecular } \\
\text { formula }\end{array}$} & \multirow[t]{2}{*}{ Colour } & \multirow{2}{*}{$\begin{array}{c}\text { Yield } \\
\%\end{array}$} & \multirow{2}{*}{$\underset{{ }^{\circ} \mathrm{C}}{\mathrm{m} . \mathrm{p}}$} & \multicolumn{4}{|c|}{$\begin{array}{l}\text { Elemental analysis\% } \\
\text { found (calculated) }\end{array}$} \\
\hline & & & & & & $\mathrm{C}$ & $\mathrm{H}$ & $\mathrm{N}$ & $\mathrm{S}$ \\
\hline 1 & $\mathrm{~L}_{1}$ & $\mathrm{C}_{16} \mathrm{H}_{13} \mathrm{~N}_{3} \mathrm{O}_{3} \mathrm{~S}_{2}$ & Yellow & 85 & 270 & $\begin{array}{c}52.93 \\
(53.48)\end{array}$ & $\begin{array}{c}3.30 \\
(3.62)\end{array}$ & $\begin{array}{c}10.81 \\
(11.69)\end{array}$ & $\begin{array}{c}17.45 \\
(17.82)\end{array}$ \\
\hline 2 & $\mathrm{~L}_{2}$ & $\mathrm{C}_{18} \mathrm{H}_{16} \mathrm{~N}_{3} \mathrm{O}_{4} \mathrm{~S}$ & Orange & 85 & 271 & $\begin{array}{r}57.79 \\
(58.37) \\
\end{array}$ & $\begin{array}{c}4.21 \\
(4.32) \\
\end{array}$ & $\begin{array}{c}10.92 \\
(11.31) \\
\end{array}$ & $\begin{array}{c}8.52 \\
(8.64) \\
\end{array}$ \\
\hline 3 & $\mathrm{~L}_{3}$ & $\mathrm{C}_{20} \mathrm{H}_{1}$ & Yellow & 80 & 264 & $\begin{array}{c}61.89 \\
(62.99)\end{array}$ & $\begin{array}{c}4.62 \\
(4.98)\end{array}$ & $\begin{array}{c}10.98 \\
(11.02)\end{array}$ & $\begin{array}{c}7.88 \\
(8.39) \\
\end{array}$ \\
\hline
\end{tabular}

\section{FT-IR spectrum}

The ligands used in the present investigation contain five donor sites: (i) phenolic oxygen, (ii) azomethine nitrogen, (iii) sulfonamide oxygen, (iv) sulfonamide nitrogen and (v) ring nitrogen. The vibrational spectra of the ligands shows a band in the region of $1616-1659 \mathrm{~cm}^{-1}$ corresponds to $v(>\mathrm{C}=\mathrm{N}-)$ group [11] and another broad band between $3456-3471 \mathrm{~cm}^{-1}$ which is the characteristic frequency of hydrogen bonded phenolic $v(\mathrm{O}-\mathrm{H})$ stretching vibration $[12,13]$. Schiff base $\mathrm{L}_{1}$ IR (solid state, $\left.\mathrm{cm}^{-1}\right)$ : $1616 \mathrm{v}(>\mathrm{C}=\mathrm{N}-) ; 3462 \mathrm{v}(\mathrm{O}-\mathrm{H}) ; 1417 \mathrm{v}_{\text {as }}\left(\mathrm{SO}_{2}\right)$; $2919 v_{\mathrm{s}}\left(\mathrm{SO}_{2}\right) ; 2924 \mathrm{v}(\mathrm{N}-\mathrm{H})$. Schiff base $\mathrm{L}_{2}$ IR (solid state, $\left.\mathrm{cm}^{-1}\right): 1616 \mathrm{v}(>\mathrm{C}=\mathrm{N}-) ; 3471 \mathrm{v}(\mathrm{O}-\mathrm{H})$; $1406 v_{\text {as }}\left(\mathrm{SO}_{2}\right) ; 2934 v_{\mathrm{s}}\left(\mathrm{SO}_{2}\right) ; 2963 \mathrm{v}(\mathrm{N}-\mathrm{H})$. Schiff base $\mathrm{L}_{2}$ IR (solid state, $\left.\mathrm{cm}^{-1}\right): 1659$ $v(>\mathrm{C}=\mathrm{N}-) ; 3456 v(\mathrm{O}-\mathrm{H}) ; 1437 v_{\mathrm{as}}\left(\mathrm{SO}_{2}\right) ; 2927 v_{\mathrm{s}}\left(\mathrm{SO}_{2}\right) ; 2938 v(\mathrm{~N}-\mathrm{H})$.

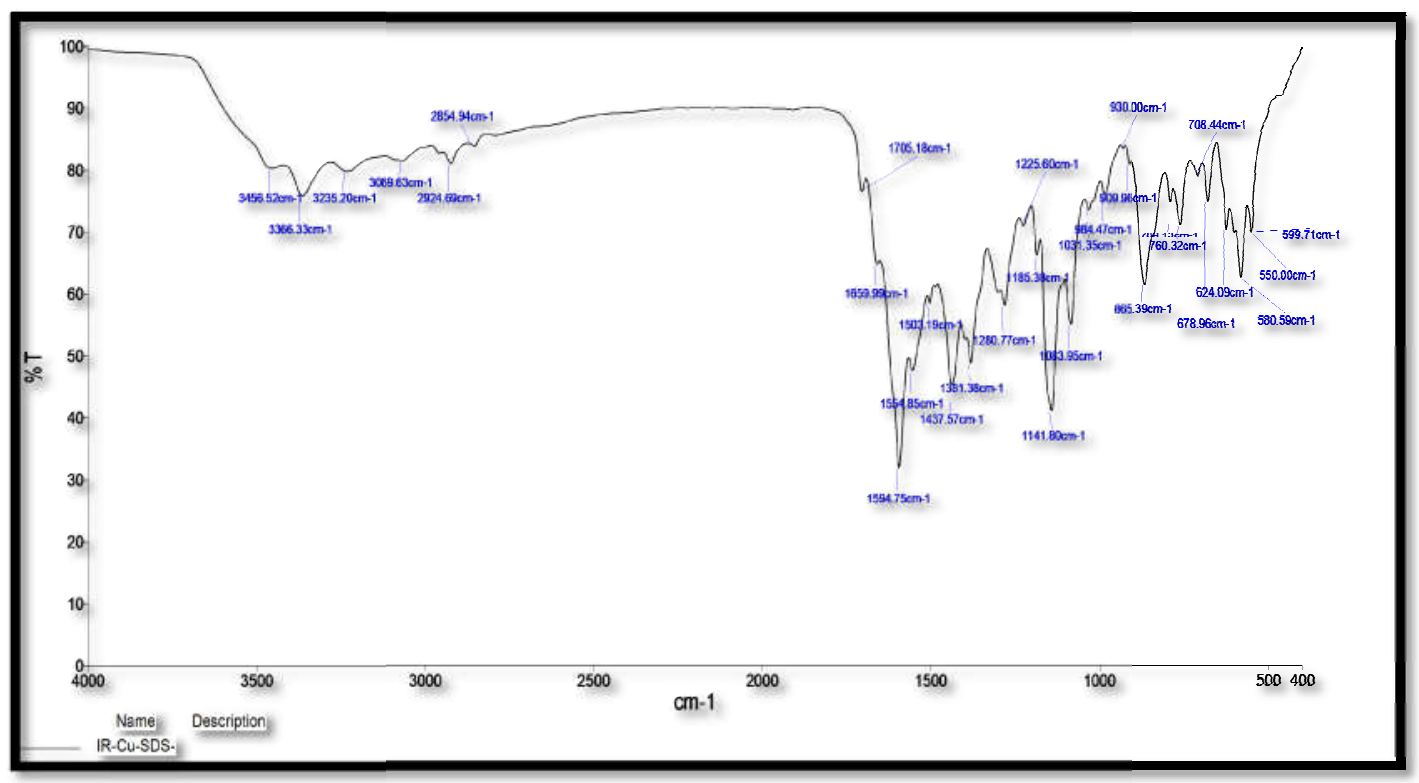

Figure 1. IR spectrum of 4-((2-hydroxybenzylidene)amino)-N-(4,6-dimethylpyrimidin-2-yl) benzenesulfonamide $\left(\mathrm{L}_{3}\right)$. 


\section{Electronic spectra}

The electronic spectra of the ligands show two absorption maxima. $\mathrm{L}_{1}\left(\lambda_{\max } \mathrm{nm}\left(\mathrm{cm}^{-1}\right): 279 \mathrm{~nm}\right.$ $\left(35842 \mathrm{~cm}^{-1}\right) \pi-\pi^{*}$ and $345 \mathrm{~nm}\left(28985 \mathrm{~cm}^{-1}\right) \mathrm{n}-\pi^{*}$ transition (azomethine linkage) [14, 15]. $\mathrm{L}_{2}$ $\left(\lambda_{\max } \mathrm{nm}\left(\mathrm{cm}^{-1}\right): 277 \mathrm{~nm}\left(36101 \mathrm{~cm}^{-1}\right) \pi-\pi^{*}\right.$ (aromatic part of the ligand) [14, 15] and $344 \mathrm{~nm}$ $\left(28985 \mathrm{~cm}^{-1}\right) \mathrm{n}-\pi^{*}$ transition. $\mathrm{L}_{3}\left(\lambda_{\max } \mathrm{nm}\left(\mathrm{cm}^{-1}\right): 276 \mathrm{~nm}\left(36231 \mathrm{~cm}^{-1}\right) \pi-\pi^{*}\right.$ and $340 \mathrm{~nm}(29411$ $\left.\mathrm{cm}^{-1}\right) \mathrm{n} \rightarrow \sigma^{*}$ transition.
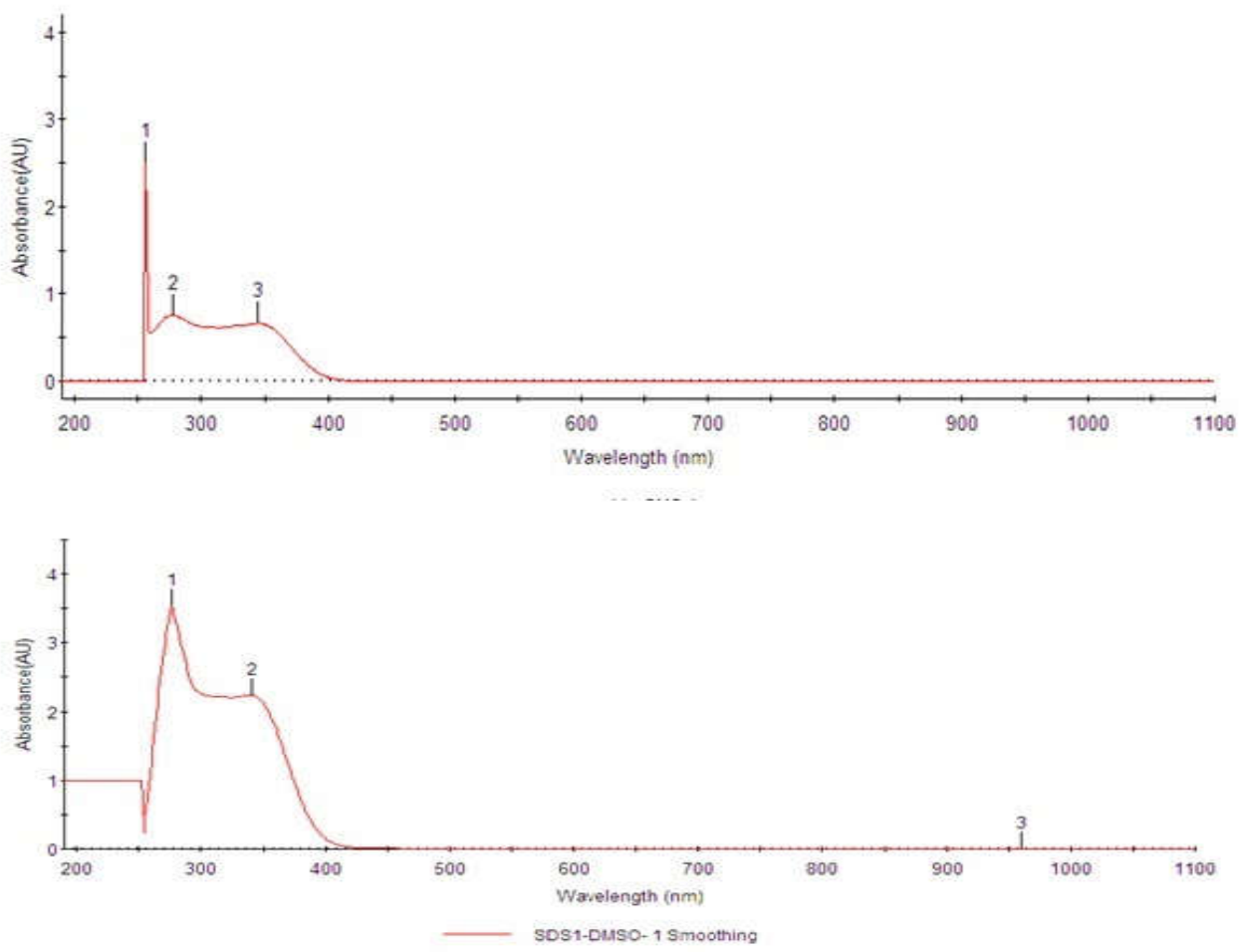

Figure 2. UV spectrum of $\mathrm{L}_{2}$ and $\mathrm{L}_{3}$.

${ }^{1} H$-NMR spectra

The proton magnetic resonance spectrum of the Schiff base was taken in DMSO- $\mathrm{d}_{6}$ solvent. The ${ }^{1} \mathrm{H}$ NMR spectrum of ligand $\left(\mathrm{L}_{1}\right)$ exhibits peak at $\delta 8.96 \mathrm{ppm}(1 \mathrm{H})$ (Figure 3 ) suggesting the appearance of $-\mathrm{CH}=\mathrm{N}$ proton [16]. The peak at $\delta 12.61 \mathrm{ppm}(1 \mathrm{H})$ and peak in the range 6.58$7.88 \mathrm{ppm}$ indicates hydroxyl and aromatic protons. The ${ }^{1} \mathrm{H}$ NMR spectrum of ligand $\left(\mathrm{L}_{2}\right)$ exhibits peak at $\delta 8.94 \mathrm{ppm}(1 \mathrm{H})$ suggesting the appearance of $-\mathrm{CH}=\mathrm{N}$ proton. The peak at $\delta$ $12.47 \mathrm{ppm}(1 \mathrm{H})$ and peak in the range 6.57-7.91 ppm indicate hydroxyl and aromatic protons [17]. The ${ }^{1} \mathrm{H}$ NMR spectrum of ligand $\mathrm{L}_{3}$ has a signal at $\delta 8.97 \mathrm{ppm}$ (Figure 3) suggesting the presence of $-\mathrm{CH}=\mathrm{N}$ - linkage. The multiplet in the proton NMR spectrum which extends from $\delta$ 6.5 to $7.6 \mathrm{ppm}$ corresponds to the ten protons of the aromatic ring. The signal at $\delta 12.6 \mathrm{ppm}$ 
indicates the presence of hydroxyl proton and $\delta 2.25$ to $2.27 \mathrm{ppm}$ corresponds to the presence of $-\mathrm{CH}_{3}$ proton. The presence of $\mathrm{NH}$ proton is confirmed by the signal at $\delta 7.7 \mathrm{ppm}$. Other peaks from ${ }^{1} \mathrm{H}-\mathrm{NMR}$ spectra for the ligands are assigned as [DMSO- $\mathrm{d}_{6}, \delta \mathrm{ppm}$ ]: 6.76-7.02 $(4 \mathrm{H}$, phenolic ring), $6.74 \mathrm{ppm}(1 \mathrm{H}$, pyrimidine) 6.98-7.70 ppm (4H, N-phenyl) [18], $7.47 \mathrm{ppm}(\mathrm{d}, 2 \mathrm{H}$, oxazole moiety), $7.45 \mathrm{ppm}$ (d, $2 \mathrm{H}$, thiazole moiety).
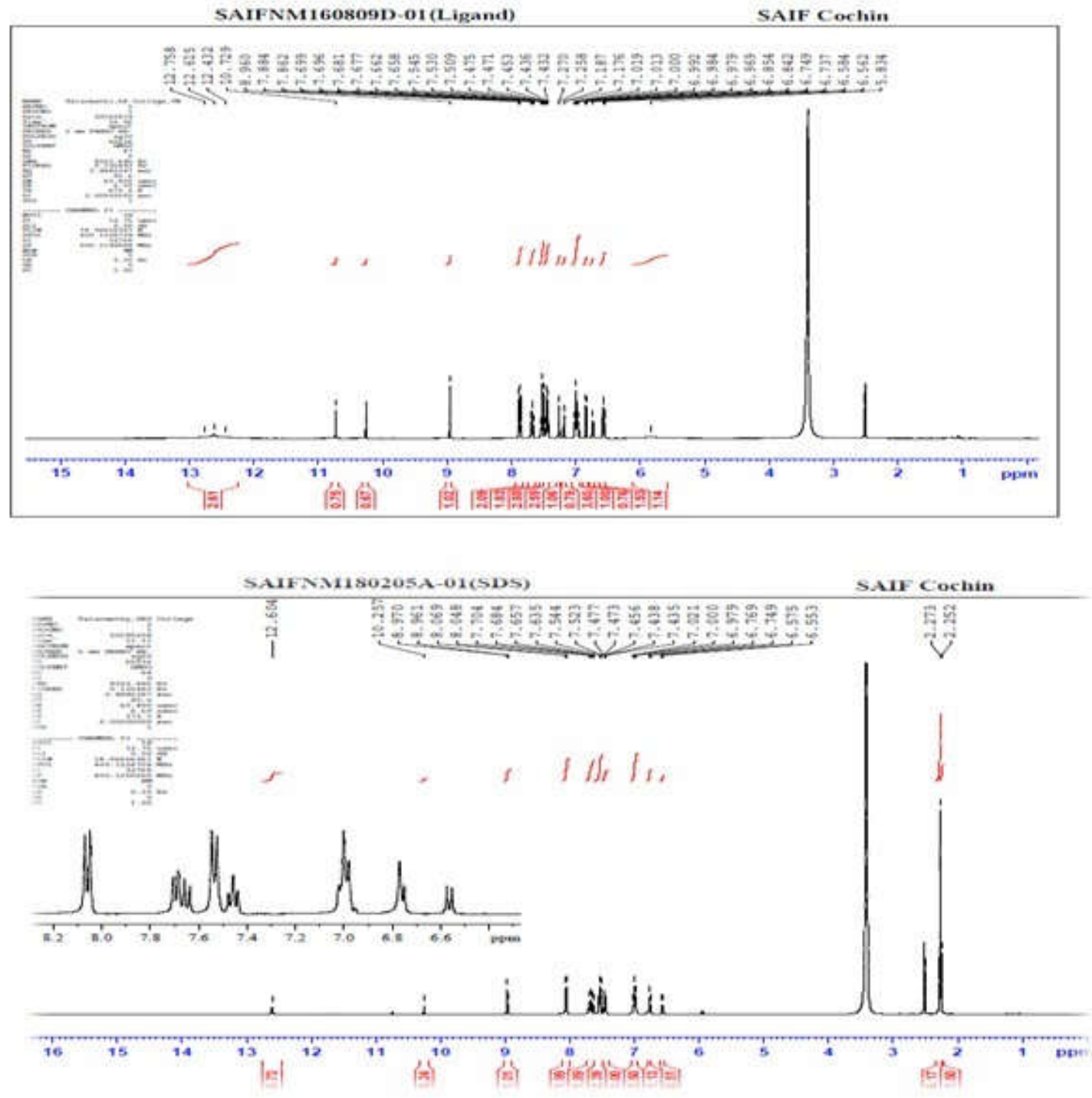

Figure 3. ${ }^{1} \mathrm{H}-\mathrm{NMR}$ spectra of $\mathrm{L}_{1}$ and $\mathrm{L}_{3}$. 
${ }^{13}$ C NMR spectra

The ${ }^{13} \mathrm{C}$-NMR spectrum of the Schiff base was taken in DMSO- $\mathrm{d}_{6}$ solvent (Figure 4$) .{ }^{13} \mathrm{C}-\mathrm{NMR}$ spectrum of $\mathrm{L}_{1}\left(\mathrm{DMSO}-\mathrm{d}_{6}, \delta\right.$, ppm): 165.1 ppm $(-\mathrm{CH}=\mathrm{N}-)$, 150.6 (phenolic $\left.\mathrm{C}-\mathrm{OH}\right), 168.8,112.4$, $147.9\left(\mathrm{C}_{1}, \mathrm{C}_{3}, \mathrm{C}_{4}\right.$-thiazole $), 122.4,127.6,140.1\left(\mathrm{C}_{2}\right.$ and $\mathrm{C}_{6}, \mathrm{C}_{3}$ and $\mathrm{C}_{5}, \mathrm{C}_{4}, \mathrm{~N}$-phenyl) 119.1, 124.4, $116.0\left(\mathrm{C}_{1}, \mathrm{C}_{2}, \mathrm{C}_{3}\right.$ and $\mathrm{C}_{4}$, phenolic) [19]. ${ }^{13} \mathrm{C}-\mathrm{NMR}$ spectrum of $\mathrm{L}_{2}\left(\mathrm{DMSO}-\mathrm{d}_{6}, \delta\right.$, ppm): $165.4 \mathrm{ppm}(-\mathrm{CH}=\mathrm{N}-) 7.47 \mathrm{ppm}(\mathrm{d}, 2 \mathrm{H}$, oxazole moiety), 160.6 (phenolic $\mathrm{C}-\mathrm{OH}) 128.2,112.5$, $152.6\left(\mathrm{C}_{1}, \mathrm{C}_{2}, \mathrm{C}_{3}\right.$-N- phenyl) $136.8,132.5,122.1,119.1,117.1\left(\mathrm{C}_{1}, \mathrm{C}_{2}, \mathrm{C}_{3}, \mathrm{C}_{4}, \mathrm{C}_{5}\right.$-phenolic ring), 169.8, 157.8, 95.2, $11.9\left(\mathrm{C}_{1}, \mathrm{C}_{2}, \mathrm{C}_{3}, \mathrm{C}_{4}\right.$, oxazolering. ${ }^{13} \mathrm{C}-\mathrm{NMR}$ spectrum of $\mathrm{L}_{3}\left(\mathrm{DMSO}-\mathrm{d}_{6}, \delta\right.$, ppm): $165.2 \mathrm{ppm}(-\mathrm{CH}=\mathrm{N}-), 150.6$ (phenolic $\mathrm{C}-\mathrm{OH}), 167.9,168.9,111.8\left(\mathrm{C} 3\right.$ and $\mathrm{C}_{5}, \mathrm{C}_{1}, \mathrm{C}_{4}$, pyrimidine $), 122.3,127.8\left(\mathrm{C}_{2}\right.$ and $\mathrm{C}_{6}, \mathrm{C}_{3}$ and $\mathrm{C}_{5}, \mathrm{C}_{4}, \mathrm{~N}$-phenyl), $115.8\left(\mathrm{C}_{3}\right.$ and $\mathrm{C}_{4}$, phenolic) [20].

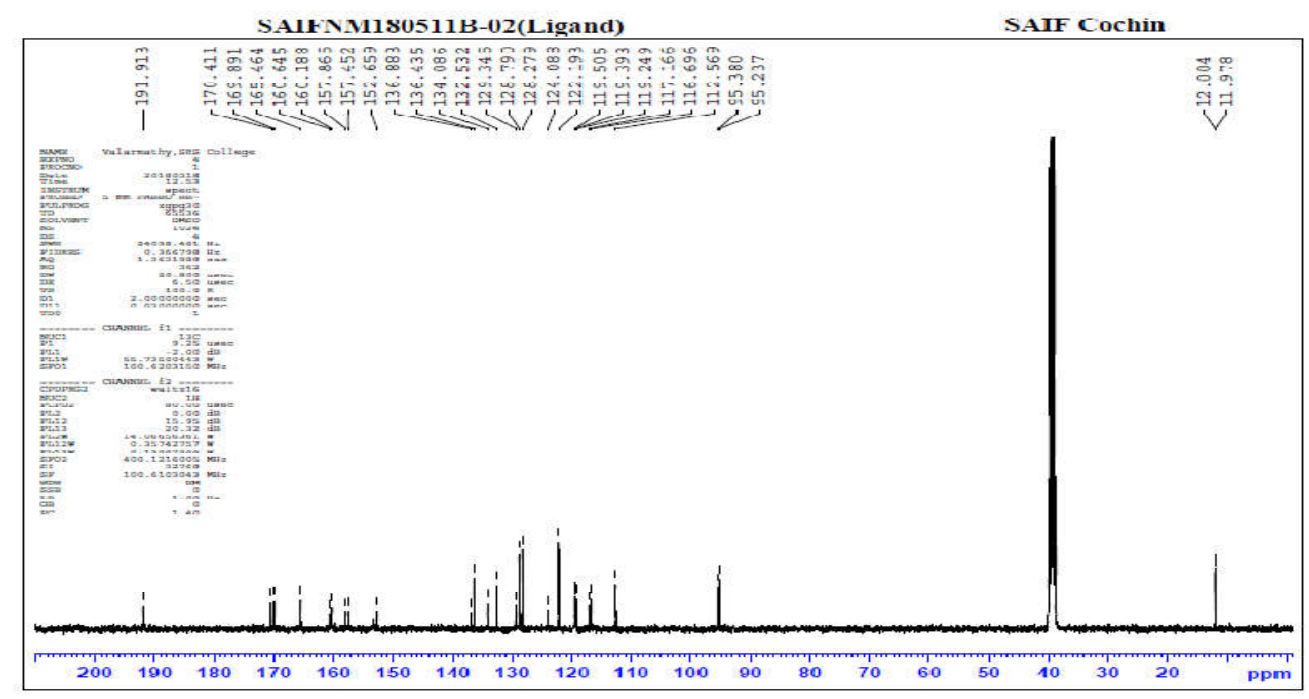

Figure 4. ${ }^{13} \mathrm{C} \quad \mathrm{NMR}$ spectrum 4-((2-hydroxybenzylidene)amino)-N-(5-methyl-1,2-oxazol-3yl)benzenesulfonamide $\left(\mathrm{L}_{2}\right)$.

\section{Mass spectra}

The mass spectral data of the ligand is consistent with the formulation corresponds to [M+3] and $\mathrm{M}$ peaks, respectively, as shown in Figure 5. Ligand-1: $\mathrm{C}_{16} \mathrm{H}_{13} \mathrm{~N}_{3} \mathrm{O}_{3} \mathrm{~S}_{2}: \mathrm{m} / \mathrm{z}=363.229$ (calcd., 359). Ligand-2: $\mathrm{C}_{18} \mathrm{H}_{16} \mathrm{~N}_{3} \mathrm{O}_{4} \mathrm{~S}: \mathrm{m} / \mathrm{z}=357$ (calcd., 357). Ligand-3: $\mathrm{C}_{20} \mathrm{H}_{19} \mathrm{~N}_{3} \mathrm{O}_{3} \mathrm{~S}: \mathrm{m} / \mathrm{z}=381$ (calcd., 381). 


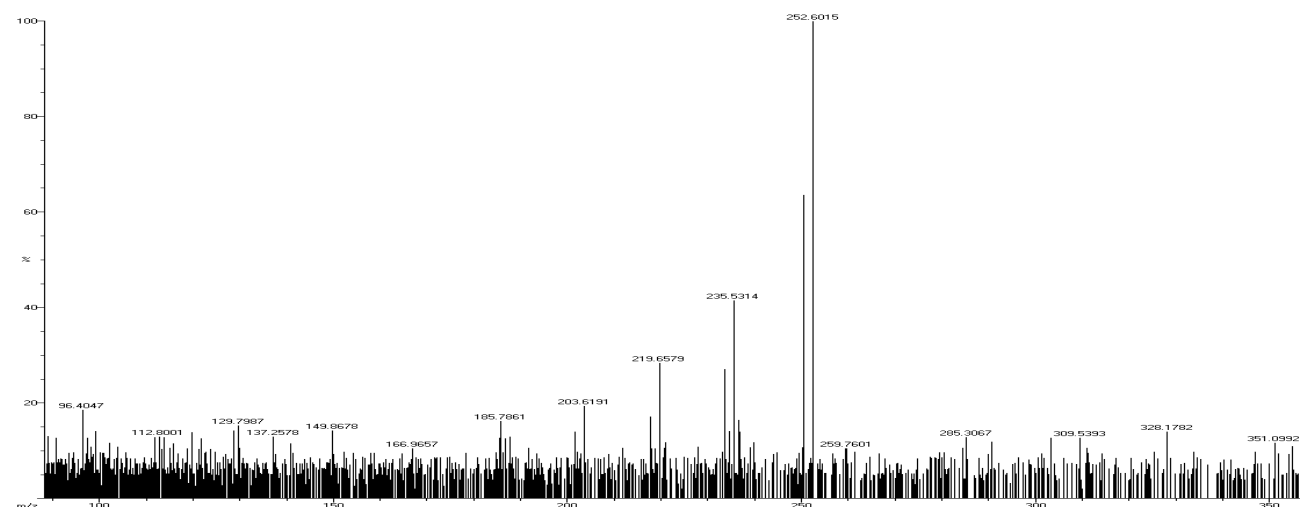

Figure 5. Mass spectrum 4-((2-hydroxybenzylidene)amino-N-(5-methyl-1,2-oxazol-3-yl) benzenesulfonamide) $\left(\mathrm{L}_{2}\right)$.

Based on the above spectral studies, the following structure is proposed for the Schiff bases:

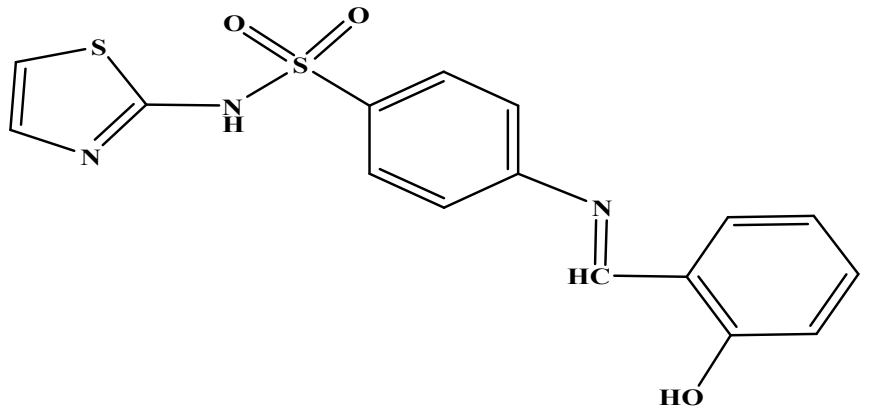

Structure of Schiff base 4-((2-hydroxybenzylidene)amino-N-(1,3-thiazol-2-yl) benzenesulfonamide $\left(\mathrm{L}_{1}\right)$.

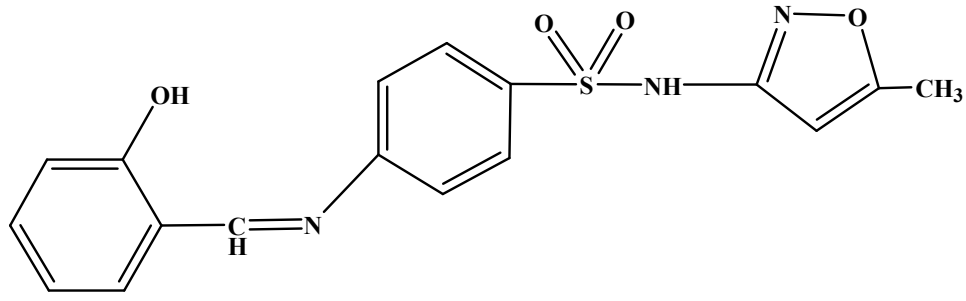

Structure of Schiff base

4-[(2-hydroxybenzylidene)amino]-N-(5-methyl-1,2-oxazol-3-yl) benzenesulfonamide $\left(\mathrm{L}_{2}\right)$. 
<smiles>Cc1cc(C)nc(NS(=O)(=O)c2ccc(/N=C/c3ccccc3O)cc2)n1</smiles>

Structure of the Schiff base 4-((2-hydroxybenzylidene)amino)-N-(4,6-dimethyl pyrimidin-2-yl) benzenesulphonamide $\left(\mathrm{L}_{3}\right)$.

\section{Anti microbial studies - minimum inhibitory concentration}

Antibacterial, antifungal and MIC activity of sulpha drugs and their Schiff base ligands have been tested by disc diffusion technique [21, 22]. The test was carried out in DMSO solution at a concentration of 50,75, $100 \mathrm{ppm}$ (Table 2). All the sulpha drugs and their Schiff bases individually exhibit varying degree of inhibitory effects on the growth of tested bacterial and fungal species (Figures 6-8).

\section{Antibacterial bioassay (in-vitro)}

Antibacterial activity of sulfa drugs and their Schiff bases were tested against bacterial species like gram positive bacteria Staphylococcus aureus and gram negative bacteria Salmonella typhi. The activity is enhanced at the concentrations 50, 75, $100 \mathrm{ppm}$. Results were compared with standard drug ciprofloxacin at the same concentration. According to antibacterial studies, the efficacy against gram negative is higher than gram positive bacteria. The inhibition of growth of bacteria is found to be maximum for the Schiff bases than the corresponding sulpha drugs. However, the Schiff base $\mathrm{L}_{2}$ is more active against Staphylococcus aureus and Salmonella typhi at lower concentration.

Table 2. Antimicrobial activity of Schiff bases and compound.

\begin{tabular}{|c|c|c|c|c|c|c|c|c|c|c|c|c|c|}
\hline \multirow{2}{*}{$\begin{array}{l}\text { S. } \\
\text { No }\end{array}$} & \multirow{2}{*}{ Compound } & \multicolumn{3}{|c|}{$\begin{array}{c}\text { Staphylococcus } \\
\text { aureus }\end{array}$} & \multicolumn{3}{|c|}{ Salmonella typhi } & \multicolumn{3}{|c|}{ Candida albicans } & \multicolumn{3}{|c|}{ Mucor } \\
\hline & & $\begin{array}{c}50 \\
\mathrm{ppm}\end{array}$ & $\begin{array}{c}75 \\
\mathrm{ppm}\end{array}$ & $\begin{array}{c}100 \\
\text { ppm }\end{array}$ & \begin{tabular}{|l|}
50 \\
$\mathrm{ppm}$
\end{tabular} & \begin{tabular}{|l}
75 \\
Ppm
\end{tabular} & $\begin{array}{l}100 \\
\text { ppm }\end{array}$ & $\begin{array}{c}50 \\
\mathrm{ppm}\end{array}$ & $\begin{array}{c}75 \\
\mathrm{ppm}\end{array}$ & $\begin{array}{r}100 \\
\text { ppm }\end{array}$ & $\begin{array}{r}50 \\
\mathrm{ppm}\end{array}$ & $\begin{array}{c}75 \\
\mathrm{ppm}\end{array}$ & $\begin{array}{l}100 \\
\text { ppm }\end{array}$ \\
\hline 1 & STS $\left(L_{1}\right)$ & 12 & 15 & 20 & 16 & 18 & 22 & 18 & 20 & 24 & 15 & 19 & 21 \\
\hline 2 & SMS $\left(L_{2}\right)$ & 14 & 19 & 22 & 20 & 22 & 30 & 16 & 18 & 22 & 18 & 20 & 22 \\
\hline 3 & $\mathrm{SDS}\left(\mathrm{L}_{3}\right)$ & 15 & 18 & 21 & 12 & 16 & 20 & 16 & 16 & 22 & 13 & 18 & 22 \\
\hline 4 & $\begin{array}{c}\text { Sulpha drug } \\
\text { ST } \\
\end{array}$ & 12 & 14 & 16 & 15 & 15 & 19 & 12 & 18 & 20 & 10 & 16 & 18 \\
\hline 5 & $\begin{array}{c}\text { Sulpha drug } \\
\text { SM } \\
\end{array}$ & 14 & 18 & 21 & 16 & 20 & 22 & 12 & 15 & 17 & 12 & 18 & 19 \\
\hline 6 & $\begin{array}{c}\text { Sulpha drug } \\
\text { SD }\end{array}$ & 14 & 15 & 18 & 12 & 12 & 16 & 10 & 12 & 14 & 14 & 20 & 22 \\
\hline
\end{tabular}

Standard $=$ Ciprofloxacin $5 \mu \mathrm{g} /$ disc for bacteria; Nystatin $100 \mu \mathrm{g} /$ disc for fungi. Highly active $=$ inhibition zone $>15 \mathrm{~mm}$; Moderately active $=$ inhibition zone $>10 \mathrm{~mm}$; Slightly active $=$ inhibition zone $>5 \mathrm{~mm}$; Inactive $=$ inhibition zone $5 \mathrm{~mm}$. 
Antifungal bioassay (in-vitro)

The sulpha drugs and their Schiff bases were carried out against fungi Candida albicans and Mucor. The activity is greatly enhanced at the concentrations 50,75, $100 \mathrm{ppm}$. Compared to the standard drug Nystatin, sulpha drugs show moderate activity against fungi, whereas the Schiff bases derived from sulpha drugs show high activity. However, the Schiff base $\mathrm{L}_{1}$ are observed to be the more active (80-85\%) against Mucor and Candida albicans.

The antimicrobial activity of the ligands are enhanced due to the mode of action of the ligands through the azomethine group with the active centers of cell constitutions, resulting in an interference with the normal cell process.

The enhancement of antimicrobial activity of the ligands as compared to sulpha drugs may be explained on the basis of Overtone's concept. According to Overtone's concept of cell permeability, the lipid membrane that surrounds the cell favours the passage of only lipid soluble materials due to which liposoluble is considered to be an important factor that controls the antimicrobial activity. The large ring size of ligand moiety makes the complexes more lipophilic. This increased lipophilicity enhances the penetration of the Schiff bases into lipid membranes of the microorganisms and block metal binding sites in the enzymes.

The Schiff bases also disturb the respiration process of the cell and thus block the synthesis of proteins, which restricts further growth of the organism. The variation in the activity of different compounds against different organisms depend either on the impermeability of the cells of the microbes or difference in ribosomes of microbial cells. Apart from this, other factors such as solubility, conductivity may also be the possible reasons for increasing this activity.

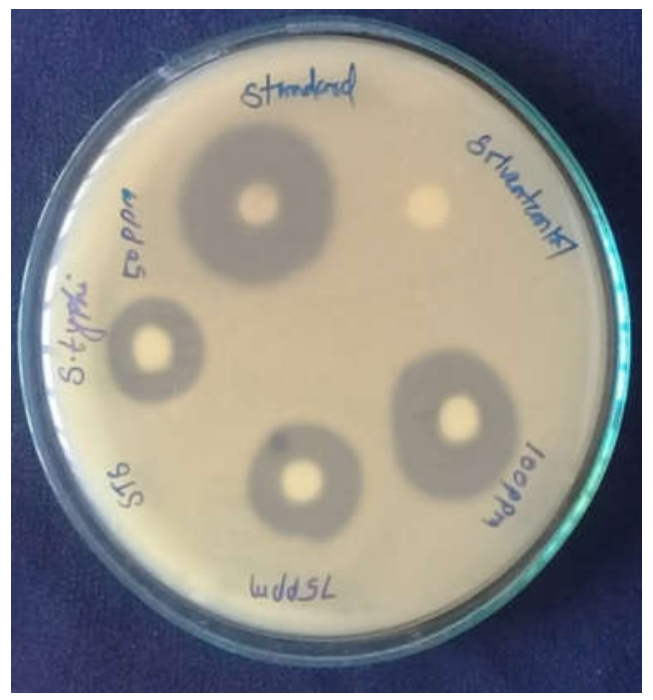




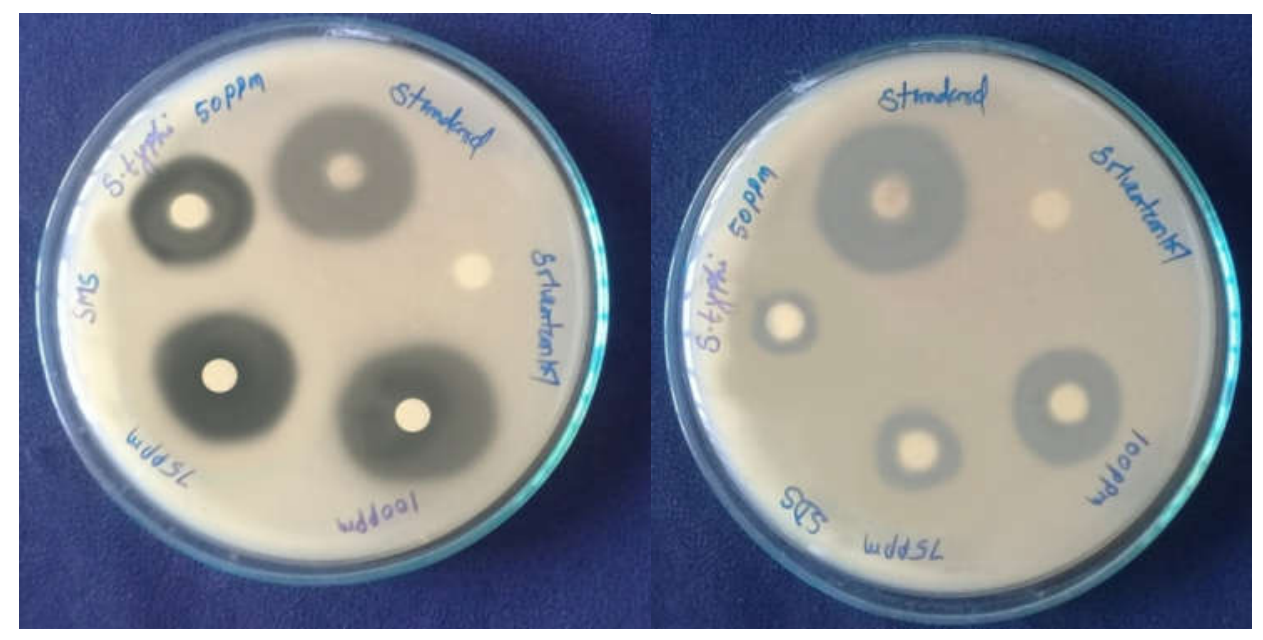

Figure 6. In vitro antibacterial screening of Schiff bases against Salmonella typhi.

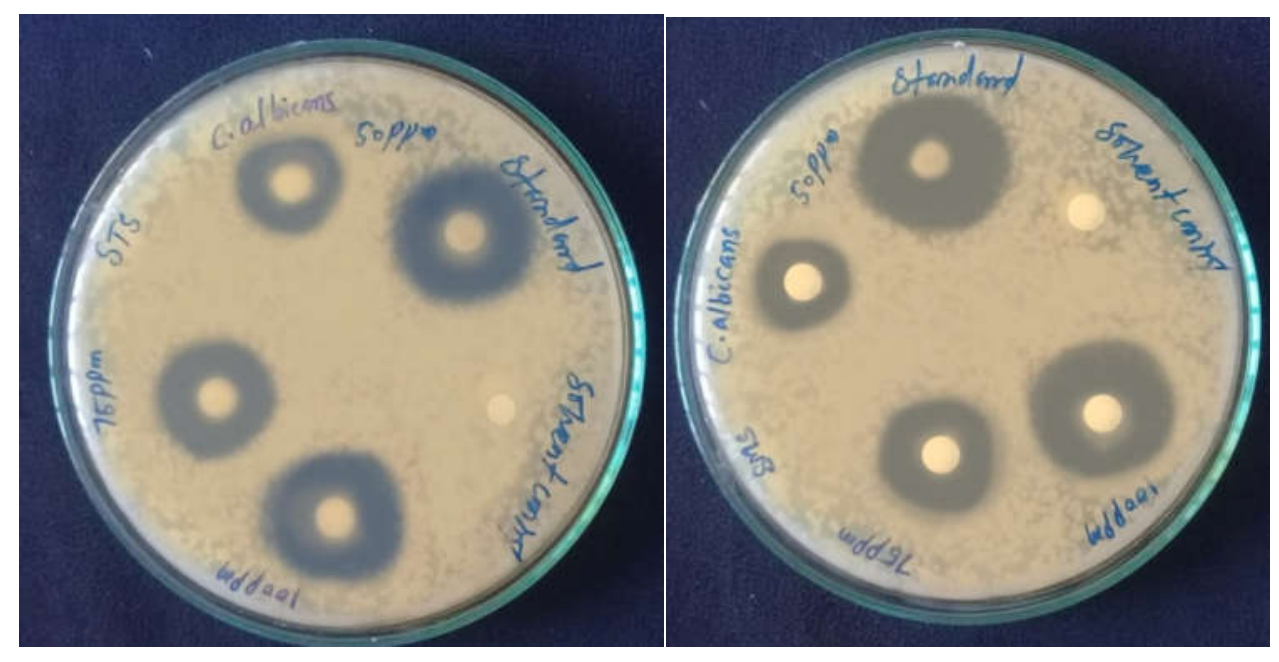

Bull. Chem. Soc. Ethiop. 2021, 35(2) 


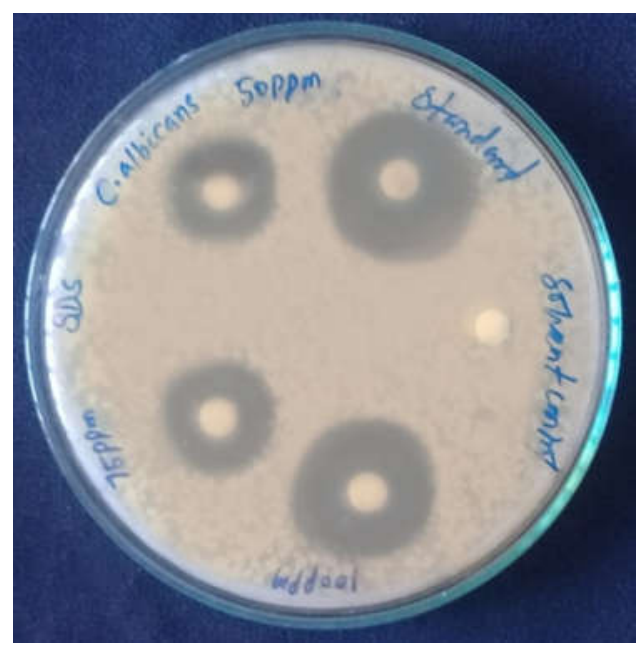

Figure 7. In vitro antifungal screening of Schiff bases against Candida albicans.
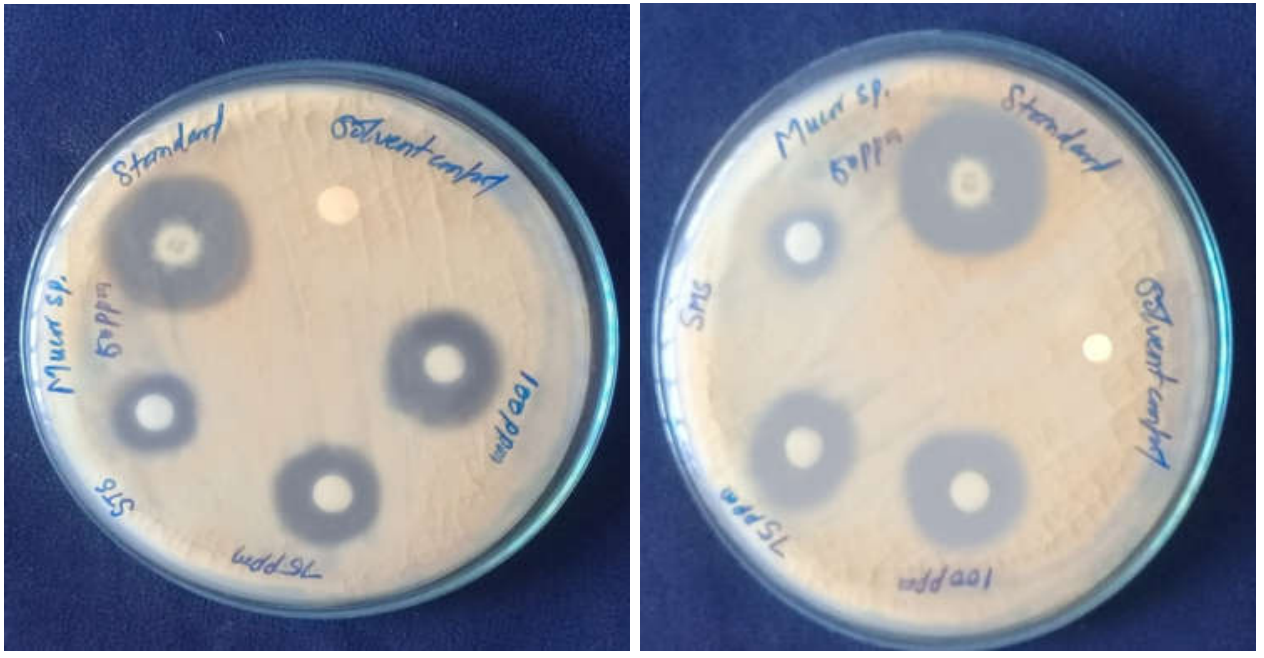

Bull. Chem. Soc. Ethiop. 2021, 35(2) 


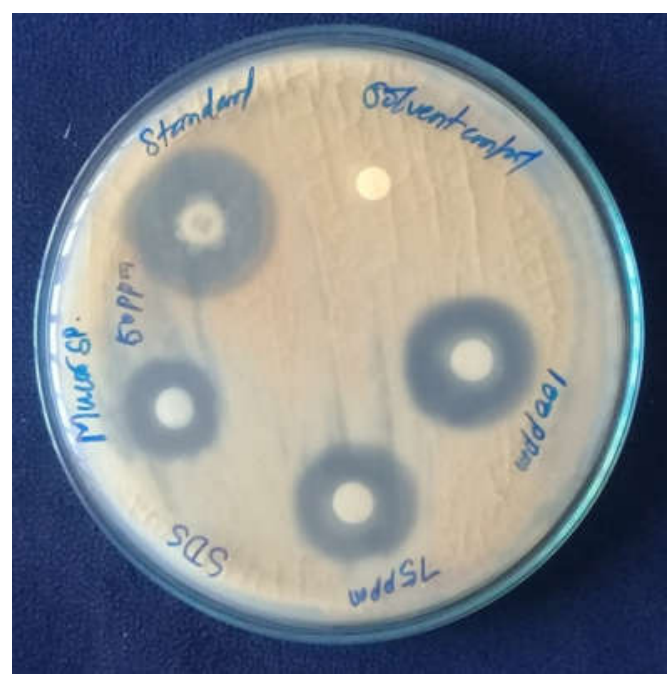

Figure 8. In vitro antifungal screening of Schiff bases against Mucor.

\section{Minimum inhibitory concentration}

The data obtained after preliminary antimicrobial screening showed that the following complexes were most active against the specified species. (1) Even at lower concentration, $50 \mathrm{ppm}$, 4-((2hydroxybenzylidene)amino)-N-(5-methyl-1,2-oxazol-3-yl)benzenesulfonamide) $\mathrm{L}_{2}$ are active against Salmonella typhi and Candida albicans. (2) 4-((2-hydroxybenzylidene)amino)-N-(1,3-thiazol-2yl)benzenesulfonamide $\quad \mathrm{L}_{1}, \quad$ 4-((2-hydroxybenzylidene)amino)-N-(5-methyl-1,2-oxazol-3-yl) benzenesulfonamide) $\mathrm{L}_{2}$ are highly active at $75 \mathrm{ppm}$ against Salmonella typhi. (3) The three synthesized Schiff bases exhibited varying degree of inhibitory effects on the Salmonella typhi and Candida albicans. On comparing the activity of ligands 4-((2-hydroxybenzylidene)amino)-N-(5methyl-1,2-oxazol-3-yl)benzenesulfonamide) $\mathrm{L}_{2}$ is more active than the 4-((2-hydroxybenzylidene) amino)-N-(1,3-thiazol-2-yl)benzenesulfonamide $\quad \mathrm{L}_{1}, \quad$ 4-((2-hydroxybenzylidene)amino)-N-(4,6dimethylpyrimidin-2-yl) benzenesulfonamide) $\mathrm{L}_{3}$. The order of activity is $\mathrm{L}_{2}>\mathrm{L}_{1}>\mathrm{L}_{3}$. The greater activity of $\mathrm{L}_{2}$ may be due to the presence of oxazole moiety in the ligand [23].

\section{CONCLUSION}

In conclusion, the bidentate coordination ability of the newly synthesized azo Schiff base was proved by IR, UV, NMR and mass spectra confirms two donor sites azomethine nitrogen and phenolic oxygen. The synthesized Schiff bases were subjected to antimicrobial activity at a concentration of $50 \mathrm{ppm}$. The order of activity is $\mathrm{L}_{2}>\mathrm{L}_{1}>\mathrm{L}_{3}$. The greater activity of $\mathrm{L}_{2}$ may be due to the presence of oxazole moiety in the ligand.

\section{ACKNOWLEDGEMENT}

The authors are thankful to the Secretary and Director, Seethalakshmi Ramaswami College, Tiruchirappalli, Tamilnadu for providing laboratory facilities and support. The authors also thankful to the Director-STIC Cochin for providing analytical support. 


\section{REFERENCES}

1. Brodowska, K.M.; Lodyga-Chruscinska, E. Schiff bases - Interesting range of applications in various fields of science. Chemik 2014, 68, 129-134.

2. Xavier, A.; Srividhya, N. Synthesis and study of Schiff base ligands. J. Appl. Chem. 2014, 7, 6-15.

3. Sutherland, J.W.; Williamson, D.E.; Theivagt, J.G. Pharmaceutical and related drugs. Anal. Chem. Ann. Rev. 1971, 43, 206-260.

4. George Kauffman, B.; Jack Halpern, J. Homogenous catalysis by coordination compounds. Coord. Chem. Rev. 1993, 128, 1-48.

5. Grammel, M.; Hang, H.C. Chemical reporters for biological discovery. Nat. Chem. Biol. 2013, 9, 475-484.

6. Kapadniskailas, H.; Jadhavsheetal, P. Four synthesis methods of Schiff base ligands and preparation of their metal complex with IR and antimicrobial investigation, World $J$. Pharm. Pharm. Sci. 2016, 5, 1055-1063.

7. Khadum; S.Y.; Ahmed, D.S.; Yousif, E. Chemical modification of PVC with Schiff Base Containing a thiadiazole moiety and its influence on the physicochemical and morphological properties. Res. J. Pharm. Tech. 2019, 12, 4518-4522.

8. Kavitha, A.; Anandhavelu, S.; Karuppasamy, K.; Vikraman, D. In vitro cytotoxicity activity of novel Schiff base ligand-lanthanide complexes. Sci. Rep. 2018, 8, 3054.

9. Daniel da silva, L.; Luziamodolo, V. Schiff bases: A short review of their antimicrobial activities. $J$. Adv. Res. 2011, 2, 1-8.

10. Mumtaz, A.; Mahmud, T.; Elsegood, M.R.; Weaver, G.W. Synthesis and characterization of new Schiff base transition metal complexes derived from drug together with biological potential study. J. Nucl. Med. Radiat. Ther. 2016, 7, 310-315.

11. Dikio, C.W.; Okoli, B.J.; Mtunzi, F.M. Synthesis of new anti-bacterial agents: Hydrazide Schiff bases of vanadium acetyl acetonate complexes. Cogent. Chem. 2017, 3, 1336864.

12. Prakash, A.; Adhikari, D. Application of Schiff bases and their metal complexes-A review. Int. J. Chem. Tech. Res. 2011, 3, 1891-1896.

13. Ming, L.J. Structure and function of metabolites. Med. Res. Rev. 2003, 23, 697-672.

14. Anacona, J.R.; Rodriguez, I. Synthesis and antibacterial activity of cephalexin metal complexes. J. Coord. Chem. 2004, 57, 1263-1269.

15. Sharda, L.N.; Ganokar, M.C. Synthesis and structural studies of oxovanadium(IV), manganese(II), iron(II), cobalt(II), nickel(II) and copper(II) complexes with new tridentate Schiff bases having ONO and ONN donor systems. Indian J. Chem. 1988, 27A, 617-621.

16. Valarmathy, G.; Subbalakshmi, R.; Gomathi, V.; Selvameena, R. Synthesis, characterisation and antimicrobial screening of $\mathrm{Co}(\mathrm{II}), \mathrm{Mn}(\mathrm{II}) \mathrm{Ni}(\mathrm{II}), \mathrm{Cu}(\mathrm{II})$ and $\mathrm{Zn}$ (II) complexes of Schiff base ligand. Orient. J. Chem. 2013, 29, 315-320.

17. John Mc Clusky, V. A new tool to aid students in NMR interpretation. J. Chem. Educ. 2007, 84, 983-986.

18. Paul Lauterbur, C. Configuration of a polyelectrolyte chain in solution. J. Chem. Phys. 1957, 26, 217-229.

19. Graham, D.M.; Holloway, C.E. Nuclear spin-spin coupling in $\mathrm{C}^{13}$-enriched acetylene, ethylene, and ethane. Can. J. Chem. 1963, 41(8), 2114-2118.

20. Matela, G.; Aman, R.; Sharma, C.; Chaudhary, S. Synthesis, characterization and antimicrobial evaluation of diorganotin(IV) complexes of Schiff base. Indian J. Adv. Chem. 2013, 1, 157-163.

21. Tavman, A.; Hacioglu, M.; Gürbüz, D.; Cinarli, A.; Faruk Oksüzömer, M.A.; Birteksoz Tan, A.S. Spectral characterization and antimicrobial activity of some transition metal complexes of 2-(5-nitro-1H-benzimidazol-2-yl)-4-bromophenol. Bull. Chem. Soc. Ethiop. 2019, 33, 451-466. 
22. Subudhi, B.B.; Ghosh, G. Synthesis and antibacterial activity of some heterocyclic derivatives of sulphanilamide. Bull. Chem. Soc. Ethiop. 2012, 26, 455-460.

23. Siraj, I.T.; Sadiq, I.A. Synthesis, characterization and antimicrobial activities of a Schiff base derived from phenylalanine and acetylacetone and its $\mathrm{Mn}(\mathrm{II}), \mathrm{Ni}(\mathrm{II})$ and $\mathrm{Cu}(\mathrm{II})$ complexes. Chemsearch J. 2016, 7, 34-39. 